Eric Neumayer,** and Thomas Plümper ${ }^{2}$

\title{
Women's economic rights in developing countries and the gender gap in migration to Germany
}

\begin{abstract}
There is a large variation across countries of origin in the gender composition of migrants coming to Germany. We argue that women's economic rights in developing countries of origin have three effects on their migration prospects to a place like Germany that is far away and difficult to reach. First, the lower are women's economic rights the fewer women have access to and control over the resources needed to migrate to Germany. Second, the lower are the rights the lower is women's agency to make or otherwise influence migration decisions. These two constraining effects on the female share in migrant populations dominate the opposing third effect that stems from low levels of women's economic rights generating a potentially powerful push factor. We find corroborating evidence in our analysis of the gender composition of migration to Germany over the period 2009-2017.
\end{abstract}

$\begin{array}{ll}\text { Current version: } & \text { August 10, 2021 } \\ \text { Keywords: } & \text { migration, economic rights, gender, resources, agency } \\ \text { JEL codes: } & \text { F22, K37, O15 } \\ \text { Corresponding author: } & \text { Eric Neumayer } \\ & \text { e.neumayer@lse.ac.uk }\end{array}$

1 Department of Geography and Environment, London School of Economics and Political Science (LSE), London, UK. E-mail: e.neumayer@lse.ac.uk

2 Department of Socioeconomics, Vienna University of Economics and Business, Vienna, Austria. E-mail: thomas.pluemper@wu.ac.at 


\section{Introduction}

In absolute numbers, Germany is by far the most popular Western European destination country for immigrants. The sheer size of the migrant inflow has generated the most political, public, and media interest. Yet, there is an important and underexplored aspect of international migration: the stark gender imbalances across the places of origin. Between 2009 and 2018, the share of women among all migrants coming to Germany was around 39\%, whereas women comprised $52 \%$ of international migrants coming to Europe and $51.5 \%$ of international migrants coming to Northern America in 2017 (United Nations, 2017:15) and the female share among German nationals is around $51 \%{ }^{1}$ These aggregate differences are substantial but they hide large variation across specific migrant populations in several destination countries (Gordon, 2005; Donato et al., 2011). In Germany, the gender gap in migrants - that is, the number of women divided by the total migrants from a country of origin - varies tremendously. The list of countries with a large gender gap is dominated by African, Arab, and South Asian countries (see Appendix 1). ${ }^{2}$ In 11 countries, fewer than $20 \%$ of the migrants coming to Germany are women. There is greater regional diversity in the set of countries where women form the majority of migrants. In five cases, the women's share is higher than two-thirds. Taken together, these are staggering gender imbalances across countries of origin.

Focusing on developing countries, we argue that the large variation in the gender composition of migrants coming to Germany from these places is not random. Building on Lawson's (1998: 39) suggestion that "migration theory can be advanced by analysing gender differences in migration processes," we explain the gender gap in migrants coming to Germany based on the availability of resources needed for the migration investment, together with the agency to make migration decisions. We argue that low levels of women's economic rights reduce women's access to and control over the resources needed to migrate to Germany as well as their agency to make or influence such decisions. When the cost of migration is substantial, as is the case for migration from most developing countries of origin to a far-away and difficult-to-reach places like Germany, these constraining effects dominate any incentive that lack of women's rights might exert to leave the country. As a consequence, countries with low women's economic rights tend to have a low women's share among migrants coming to Germany and we find evidence for this hypothesis in our empirical analysis of the gender gap in migration from 112 developing countries over the period 2007-2017 that is robust to various model specification choices. ${ }^{3}$

Naturally, we do not claim that our explanation is the only factor determining the gender gap in migration. Instead, it should be regarded as complementary to other factors which we control for both in the baseline and in the robustness test model specifications. In this respect, we find that there is path dependency, likely due to migration network effects, where a higher or lower gender gap in the previous year predicts a higher or lower gender gap the year after. Relatively more women come from geographically more distant places of origin and from countries for which a visa is required to enter Germany.

1 Throughout, all migration-related data for Germany are taken from the German Federal Statistics Office (www-genesis. destatis.de).

2 We only show countries from which there are at least 1,000 migrants coming to Germany over the 2009-2018 period.

3122 developing countries in one robustness test. 
Our paper contributes to a growing social science literature analyzing gender-specific dimensions of international migration comparing countries of origin as well as countries of destination (Gordon, 2005; Donato et al., 2011; Bang and Mitra, 2011; Docquier et al., 2012; Baudassé and Bazillier, 2014; Naghsh and Young, 2014; Ferrant and Tuccio, 2015). ${ }^{4}$ The three most recent studies are the most relevant to us. Baudassé and Bazillier (2014) study the impact of gender inequality in the labor market, as measured by gender differences in education ratios, unemployment rates, income ratios, and labor market participation rates on migration flow between up to 151 countries in 1991 and 2001. They thus pool migration across all countries, including migration from the Organisation of Economic Co-operation and Development (OECD) countries to other OECD countries, except in one robustness test where they find that their measures of gender inequality in the labor market sometimes do not have a statistically significant association with migration of women from non-OECD countries to OECD countries, and occasionally even a negative effect. This study's empirical research design is not directly comparable to our study, since gender inequality in the labor market is different from women's economic rights as broadly defined in our study, and our empirical analysis is focused on developing-country migration to Germany. In an unpublished discussion paper, Naghsh and Young (2014) entirely focus on the migration of the highly skilled between both developing and developed countries in the years 1990 and 2000, for whom they find that small reductions in the gap in women's rights increase outmigration but large reductions reduce outmigration. Our theoretical argument applies to and our empirical analysis covers all migration independently of skill level, including that of refugees seeking protection status in Germany. Lastly, Ferrant and Tuccio (2015) study the effect of women's rights on emigration and find, for the year 2010, a positive net migration flow out of countries that discriminate more against women and toward countries that discriminate less against women. At first glance, this finding contradicts our result that low levels of women's rights in migrants' home countries reduce the women's share in migrants coming to Germany. Yet, our results are not necessarily inconsistent with Ferrant and Tuccio's findings. It may well be that more women leave places in which discrimination against women prevails, while at the same time these women do not manage to migrate to Germany but rather migrate to a nearby country. Migration from one developing country to a nearby developing country - a pattern that drives the findings of Ferrant and Tuccio requires less access to resources and less in terms of agency and aspirations than migrating to Germany.

\section{Women's Economic Rights and their Effect on the Gender Composition of Migrants}

International migration decisions are the result of complex choices that any single explanation cannot do full justice to (Baláž et al., 2016). With this caveat in mind, this section develops an explanation for gender imbalances in migrants coming to Germany based on the effect that women's economic rights in countries of origin have on access to and control over resources as well as agency to make or influence migration decisions. Our explanation is

4 In addition, Ruyssen and Salomone (2018) study the effect of perceived gender discrimination on migration intentions, rather than actual migration, and self-stated preparatory behavior at the individual level. 
based on a theory of international migration in which agents make migration decisions based on comparing expected utility from migrating from their home to a destination country relative to remaining in their home country, which is common in economic theory (Hatton and Williamson, 2005). Importantly, these decisions are subject to resource constraints agents face and it is not necessarily individuals who are the agents making decisions, but larger units such as families or even wider kinship groups. Both factors play a crucial part in our argumentation.

We start with a closer look at the importance of resources for migration, which both at the individual and the macrolevel has been demonstrated to play a major role. At the individual level, Ruyssen and Salomone (2018) show that household income plays a much bigger role in making the next step toward preparing for migration than it does in shaping migration intentions, with the estimated effect being more than five times larger for migration preparation than for migration intention. At the macrolevel, the effect of resource constraints has been most clearly established in the form of an empirical regularity: the existence of a nonlinearity in the relation between a country's per capita income and outward migration from that country. The migration hump, as Vogler and Rotte (2000) have dubbed this regularity, depicts an inverse- $U$ shaped relationship between a country's per capita income and the size of outward migration from this country of origin: an improvement of economic conditions in a very poor country increases the number of migrants leaving the country, while a similar improvement in economic conditions at higher levels of per capita income reduces emigration.

The migration hump regularity results from two different causal mechanisms at play. On one hand, poor economic conditions increase the incentives to migrate since the wage gap between the home country and the potential destination country is bigger. On the other hand, poor economic conditions also reduce the ability to migrate, as migration is costly and requires command over sufficient resources. As Faini and Venturini (1993) point out, individuals interested in leaving their home country are likely to be more financially constrained in very poor countries. Migration requires some upfront expenditures that very poor and liquidity-constrained people will not be able to afford. Hatton and Williamson (2002: 5) call this the "poverty constraint on emigration." Likewise, liquidity constraints will limit the ability of would-be migrants to take advantage of migration networks that have been shown to provide essential support (Tiwari and Winters, 2019). As a consequence, people who are stripped from access to resources will often not be able to migrate and, in case they have to flee, will almost never be able to flee further than across the next border. In the poorest countries, the vast majority of people face severe restrictions on their resources and this constraining resource effect thus dominates. As economic conditions improve, liquidity constraints become relaxed and more and more people can afford to invest in migration (Faini and Venturini, 1993; Tiwari and Winters, 2019). Eventually, as per capita income rises further and further, while even more people now enjoy the resources necessary for migration, economic conditions improve sufficiently, thus lowering again the incentives to migrate.

Analogous reasoning suggests that restrictions on women's economic rights are likely to have two effects on the gender gap in migration to Germany. On one hand, restrictions on women's rights increase the incentives for women to leave the country, the push factor. 
However, rights restrictions also reduce women's control over and access to resources (Iqbal, 2015), are likely to impose more severe liquidity constraints onto them compared to men, and therefore reduce the ability of women to migrate. Thus, in this respect, the effects of restrictions on women's rights on the outward migration of women are a priori ambiguous (Ruyssen and Salomone, 2018). However, for migration from developing countries to a far-away place like Germany which is costly to reach, the resource restriction effect should dominate and restrictions on women's economic rights should therefore lower the female share in migrant populations. By contrast, the costs of migration from another European Union (EU) country are low given the geographical proximity and given that European legislation grants the citizens of EU members the right to seek employment in all EU countries and extends social welfare benefits to all EU citizens if these are "habitual residents" of the country in which they claim benefits.

The effect of women's economic rights on access to and control over resources has been stressed in the literature on women's empowerment. At the same time, and this forms the second component of our argument, women's economic rights also affect their agency to make migration decisions, a factor stressed and elaborated in some detail by Baudassé and Bazillier (2014). Women's economic rights have a direct impact on the power relations between men and women. As Kabeer (1999: 437) writes: "One way of thinking about power is in terms of the ability to make choices: to be disempowered, therefore, implies to be denied choice. (...) The ability to exercise choice can be thought of in terms of three interrelated dimensions: resources, agency, and achievements. Resources include not only material resources in the more conventional economic sense but also the various human and social resources which serve to enhance the ability to exercise choice." Applied to migration choices, women need to have sufficient command over resources, not limited to but including the material resources required to migrate. Yet, the agency component of women's empowerment is also highly relevant to migration because individuals do not necessarily make independent choices on migration. Low women's economic rights have a pronounced effect on the female share of migrants from developing countries given that families or social kin groups play an important role in international migration decisions, since migration aims at minimizing risks to family incomes as the new economics of labor migration emphasizes (Massey et al., 1993; Heering et al., 2004). Family members abroad often serve as a major source of income providing social insurance for the family members back in the country of origin. Migration is an investment in a better future not only for the migrating individual but also for the kin left behind, some of whom may join the migrant later on.

When migration becomes a family investment decision and the family can only afford to send a single member abroad, gender can be expected to play a major role (De Jong, 2000). In this situation, the family will usually send the family member that in their view has the best chances to generate sufficient income abroad to support the family members staying behind. In societies in which women's economic rights are restricted, daughters count less than sons and due to low economic rights they are unlikely to be perceived to be better suited than men to generate income abroad. As a consequence, the family is more likely to select a son as the best candidate for migration. The gender composition of migrants thus reproduces and reflects women's economic rights and gender stereotypes at home. 
One might wonder whether this argument also applies to refugees who represent the majority of migrants from developing countries to Germany. ${ }^{5}$ At least those forced to flee must leave with little choice. And yet, once families have reached a relatively safe space within their home country as internally displaced people or have reached a safe country close to their home country, migration further abroad becomes a family investment. Whereon migration to, for example, Europe (or other developed countries) is very costly, the family singles out whom the family deciders perceive as the likeliest candidate for generating an income in Europe, sufficient to provide an additional source of revenue to the family. If the investment pays out, the migrating family members not just send money back to those other family members left behind (Butsch, 2020), but might also manage to bring additional family members to Europe. Many families can only afford to buy the trip to Europe for one of their members. Coming from a country in which women face restrictions on their economic rights, these families will see their best chance in sending young males first rather than a female. This logic can explain why half of the civil war refugees who came to Germany from Yugoslavia in the 1990s were women, but only $30-40 \%$ of the recent refugees from Syria, Afghanistan, Iran, and Iraq are female. Germany is in easy reach of Yugoslavia but is far more difficult and expensive to get to from Syria, Afghanistan, Iran, and Iraq - let alone from sub-Saharan Africa, which can also explain why the Central Mediterranean refugee routes are more male-dominated than the Eastern Mediterranean routes (Kofman, 2019).

To sum up, our explanation suggests an effect of women's economic rights on the gender composition of migrants coming to Germany that goes against the push-factor effect in which lack of rights pushes women to migrate abroad. Restrictions on women's economic rights reduce women's access to and control over resources and reduce their agency to make or influence migration decisions. These rights restrictions not only provide incentives for migration, but also severely limit the ability of women to translate migration intentions into actual migration - with the latter constraining effects dominating the opposing incentivizing effect for migration from developing countries. In the remainder, we put this hypothesis to an empirical test, controlling for other factors that also potentially impact the gender gap in migration to Germany.

\section{Research Design}

This section describes the research design on which the empirical analysis testing our hypothesis is based. Our dependent variable is the share of women among migrants coming to Germany for each developing country of origin and year. Migrants are defined as those who

5 We use the term "refugees" throughout, though formally one would need to distinguish between asylum-seekers, refugees, and individuals seeking other forms of protection. Asylum-seekers and refugees form subsets of all individuals seeking protection. Protection can be granted open-ended or time-limited and comes in various forms (BAMF 2019). The strongest form is based on asylum protection, which requires that the person granted asylum was persecuted by state actors on the basis of their race, nationality, political orientation, religious conviction, or belonging to a particular social group (including groups based on sexual orientation) and continues to be threatened with violations of their human rights if they were to return to their country of origin. If asylum is denied, protection can be granted in the form of refugee protection under the Geneva Refugee Convention. The grounds for granting protection are the same as under asylum, except that persecution can come from non-state actors, too. Failing that, subsidiary protection can still be granted for a person who can persuasively demonstrate that returning to their country of origin would result in significant personal harm to them in the form of the death penalty, torture, inhuman or degrading treatment or punishment or fear of life or a serious individual threat to the life or integrity of the person, including rape, as a result of arbitrary force within an international or domestic armed conflict. 
move to Germany from abroad in a particular year, that is, excluding those who are born to foreign parents in Germany. They include all refugees, asylum seekers, and other people seeking protection in Germany. Data provided by the German statistical office distinguish migrants by their nationality and sex and cover the period 2007-2018. However, the period of our sample is 2009-2017 due to the availability of data on the explanatory variables. The quality of the data for our dependent variable is considered to be high by the German statistical office, since Germany takes the registration of foreigners very seriously: every town and county has a special office for foreigners (Ausländerbehörde) that is legally obliged to register foreigners and pass on detailed information to a central register of foreigners (Ausl än der zen tral register). Further data input comes from the federal agency looking after refugees until these have been allocated to towns and counties and registered there.

We measure women's economic rights using data from the OECD's Social Institutions and Gender Index (https://www.genderindex.org/), which is also used by Ferrant and Tuccio (2015). Specifically, we employ the three subcomponents "discrimination in the family," "restricted physical integrity," and "restricted access to productive and financial resources." Appendix 2 provides an overview of the aspects of women's rights that enter each subcomponent. We aggregate the subcomponents, which run from 0 to 100, to a single measure as follows following the same methodology as the OECD:

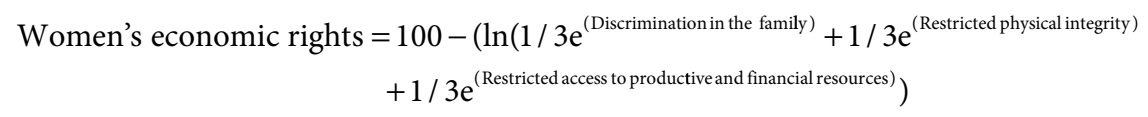

Note that this operationalization reverses the direction of this measure such that higher values mean higher women's economic rights rather than higher discrimination against women. It has a mean of 50.7, with a minimum of 1.1 , a maximum of 94.8 , and a standard deviation of 21.4. Clearly, women's economic rights vary very substantially across developing countries of origin.

This measure based on the OECD's Social Institutions and Gender Index has the advantage that it goes beyond de jure rights by additionally taking into account social norms and practices and that it exhibits substantial variation over time. However, it is only available for the years 2009, 2012, 2014, and 2019, so we interpolate the measure for the years in between. In a robustness test, we use an alternative women's economic rights measure instead, sourced from the World Bank's Women, Business and the Law database (https://wbl.worldbank.org/). Coding discrimination for aspects such as "going places," "starting a job," "getting paid," "getting married," "having children," "running a business," "managing assets," and "getting a pension," the dataset comprehensively identifies legal barriers to women's economic participation. Appendix 3 provides an overview of the coding of the data underpinning this alternative to our central explanatory variable. We use the aggregate women's economic rights index, which measures the proportion of laws that provide women with the same rights as men. While having the disadvantage of only measuring de jure women's rights and having extremely limited over-time variation, it is available for a larger sample of developing countries and, at the same time, enables us to test whether our hypothesis only holds for a specific measure of women's rights or is robust to this alternative measure. The two variables are correlated at $r 0.61$ with each other. 
We control for other confounding factors in countries of origin potentially influencing the women's share amongst migrants. The most important potential confounder stems from migrant network effects (Boyd, 1989; Massey et al., 1993; Manchin and Orazbayev, 2018), particularly but not exclusively in the form of extended family ties. While Davis and Winters (2001) find no difference in the importance of network ties for subsequent migration for female as opposed to male migration from Mexico to the United States and Beine and Salomone (2013) find that network effects do not vary by gender, we cannot exclude the possibility that such network effects create path dependency in the gender gap in migration. If for whatever reason migration from a particular country of origin starts as a gendered process, then such network effects can reinforce the gender gap over time. For example, it could be that job opportunities in certain sectors that attract more women or more men from certain countries create a gender gap in migration from these countries, and then relatively more women or more men follow from these countries in subsequent years due to migrant network effects. Curran and Rivero-Fuentes (2003) finds that for Mexican women having access to a prior female migrant network in the United States is important for facilitating their international migration and the same holds for men's access to a male migrant network for facilitating their international migration To control for such path dependency, we include the lagged dependent variable in our estimations.

Other facilitating factors that lower the costs and risks associated with international migration from origin to destination country come from geographical proximity, former colonial ties, cultural and language similarity, and the ease by which migrants from a particular country of origin can enter the destination country legally or illegally. Many of these factors affect men and women evenly and therefore cannot explain gender imbalances in migrant populations. Geographical distance and the risks and dangers of migration from far-away places have featured prominently in media coverage and popular arguments aimed at explaining the large share of men in the composition of refugees coming to Germany (Wanner, 2016). ${ }^{6}$ These explanations suggest that long-distance migration is riskier and more dangerous for vulnerable women than for men, and therefore the majority of refugees from these places are male - see, however, Kofman (2019) for a more nuanced discussion of vulnerabilities. We, therefore, control for the geographical distance to Germany with data taken from the GeoDist database (Mayer and Zignago, 2011) and whether Germany imposes a visa restriction for travel from a country of origin with data taken from Czaika and Neumayer (2017).

Geographical distance and visa restrictions are the often used variables in gravity models of international migration (Barthel and Neumayer, 2015; Beine et al., 2016) as are the remainder of our control variables. We include the per capita income in the country of origin as well as its growth rate, the country's level of democracy (using the polity2 variable of the Polity IV project) and a dummy variable set to one if the country of origin experiences a major episode of political violence in the form of civil or ethnic war. Gross Domestic Product (GDP) data are sourced from the International Political Economy Data Resource (Graham and Tucker (2019) who combine World Bank with Penn World table data), democracy, and war data come from the Center for Systemic Peace. ${ }^{7}$

6 A typical example for this line of argumentation is Peter Maxwell's article in the online version of the German weekly news magazine "Der Spiegel" (http://www.spiegel.de/kultur/gesellschaft/fluechtlinge-warum-vor-allem-maennernach-deutschland-kommen-a-1051755.html).

7 https://www.systemicpeace.org. 
In addition to conditions in countries of origin, economic conditions and immigration policies in destination countries have been shown to present important factors in international migration (Ortega and Peri, 2013). German policies and aspects of the German economy may thus also affect men differently from women. We control for these factors with the help of year fixed effects, which account for time-varying aspects of German policies and the German economy that affect men and women differently over time but equally across countries. For example, year fixed effects account for time-varying demand for foreign labor in the healthcare system, which traditionally has been an employment domain predominantly for women, or for foreign labor in the information technology sector, which tends to be more male-dominated. We readily admit that we cannot control for aspects of German policy or the German economy that both affect men and women differently and that vary strongly across different countries of origin.

We estimate the following equation:

$$
\begin{aligned}
\gamma_{i t}= & \beta_{1} y_{i t-1}+\beta_{2}(\text { women's economic rights })_{i t}+\beta_{3}(\text { p.c. income })_{i t}+\beta_{4}(\text { growth in p.c. income })_{i t} \\
& +\beta_{5}(\text { polity })_{i t}+\beta_{6}(\text { major political violence dummy })_{i t}+\beta_{7}(\text { ln distance to Germany })_{i} \\
& +\beta_{8}(\text { visa requirement dummy })_{i}+\eta_{t}+\lambda_{i}+\varepsilon_{i t}
\end{aligned}
$$

where $y_{i t}$ is the gender gap in migration from developing source country $i$ to Germany in year $t$. Appendix 4 provides descriptive summary statistics for our dependent and substantive explanatory variables. The $\eta_{t}$ term represents year fixed effects and $\lambda_{i}$ stands for a country-specific error term which we will allow to be randomly distributed with a mean of 0 in one set of estimations and fixed in another set of estimations. The error term $\varepsilon_{i t}$ is presumed to be independent and identically distributed but clustered on countries of origin, which accounts for the fact that observations from the same country of origin across multiple years are not independently distributed. Where the country-specific error term is presumed to be randomly distributed, we use a linear random effects estimator. Where the $\lambda_{i}$ are presumed to be fixed, estimating Eq. (1) would suffer from Nickell (1981) bias, which is why we estimate it with Blundell and Bond's (1998) one-step system estimator to account for the lagged dependent variable being correlated with the unobserved country fixed effects. Note that all the fixed effects model estimations pass the necessary Arellano and Bond test for zero autocorrelation in first-differenced errors with the exception of two robustness test models. ${ }^{8}$ Fixed effects estimation eliminates any bias from omitted time-invariant source country variables in the form of, for example, potentially higher risk and danger for women to reach Germany from certain locations but also other heterogeneity in, for example, historical, cultural, religious, and other societal factors that remain approximately time-invariant over our period of study. However, by eliminating all between-variation the estimation not only becomes less efficient but also, crucially, changes the hypothesis tested from whether a larger share of women come from countries with higher levels of women's economic rights to whether, over time, a larger share of women arrive from countries in years in which this country has, by its own country standards, relatively high economic rights.

8 Specifically, model M16 where we restrict the sample to countries with more than 500 migrants coming to Germany as well as model M22, albeit only marginally so at the $10 \%$ level, where we allow all explanatory variables to be endogenous and restrict the use of lagged variables as instruments to two for both the dependent variable and the endogenous explanatory variables. We cannot reject the hypothesis that these two particular models may be misspecified. 
We estimate Eq. (1) for a sample of developing countries. We define developing countries as all countries minus EU countries, the three European Free Trade Association (EFTA) countries Iceland, Norway, and Switzerland whose citizens enjoy almost the same rights in Germany as those of EU countries, as well as an additional five high-income developed countries. ${ }^{9}$ In our main estimations, we have 112 countries in the sample though sample size increases to 122 countries in the robustness test in which we replace the women's economic rights variable based on OECD data with the variable based on World Bank data. Appendix 5 provides a list of countries in the sample.

\section{Results}

Table 1 reports the baseline estimation results for Eq. (1), once estimated with random effects (Model 1) and once with fixed effects (Model 2). This model specification will be subjected to various robustness tests in the following section. As is clear from Table 1, the women's economic rights variable has the expected positive and statistically significant effect independently of whether we estimate the model with country random or fixed effects, though it is larger in the fixed effects Model 2. In substantive terms and with reference to Model 1, an increase of one standard deviation in the women's rights measure, which is one measure of the observed variation in this variable, is predicted to increase the women's share of migrants coming to Germany by approximately 1.7 percentage points. Raising women's economic rights from its minimum to its maximum increases the women's share of migrants by approximately 7.4 percentage points. The effect of women's rights on the gender gap in migration is therefore substantively important.

With respect to the control variables, in random effects estimation, we do not find that per capita income, economic growth, democracy, or the presence of major political violence impacts upon the gender share of migrants. A larger share of women come from countries of origin that are geographically more distant to Germany and from countries that require a visa to enter Germany. Our results thus do not at all support the presumption that women are deterred from migrating to Germany from far-away or more difficult-to-reach places.

\section{Robustness Tests}

Every baseline model is necessarily based on some specification decisions for which plausible alternatives exist (Neumayer and Plümper, 2017). We, therefore, submit our baseline model to several robustness tests to explore whether our central finding upholds if we employ alternative plausible specifications.

The first test explores whether our findings depend on the way our data source measures women's economic rights. In Models 3 and 4, we replace the OECD measure with the World Bank measure of women's de jure economic rights. Note that because the World Bank's de jure women's economic rights measure has very little over-time variation, we cannot estimate Model 4 with country fixed effects and instead employ fixed effects for 16 origin country subregions,

9 Specifically, Australia, Canada, Japan, New Zealand, and the United States. See Appendix 4 for a list of developing countries in the sample. 
Table 1. Women's economic rights and the female share of migrants from developing coming to Germany

\begin{tabular}{lcc}
\hline & M1 & M2 \\
\hline (Women's share of migrants) $_{\mathrm{t}-1}$ & $0.771^{\star \star \star}$ & $0.433^{\star \star \star}$ \\
Women's economic rights & $(0.034)$ & $(0.075)$ \\
& $0.079^{\star \star \star}$ & $0.089^{\star \star}$ \\
Per capita income & $(0.016)$ & $(0.045)$ \\
& 0.074 & -0.414 \\
Growth in per capita income & $(0.048)$ & $(0.554)$ \\
& 0.053 & 0.021 \\
Democracy (polity2) & $(0.034)$ & $(0.032)$ \\
& 0.017 & 0.105 \\
Major political violence dummy variable & $(0.054)$ & $(0.216)$ \\
& -0.525 & -1.397 \\
Distance to Germany (In) & $(1.105)$ & $(3.768)$ \\
& $1.687^{\star \star \star}$ & \\
Visa requirement dummy variable & $(0.588)$ & \\
Country effects & $1.237^{\star \star}$ & \\
Year fixed effects & $(0.618)$ & \\
Observations & Random & Fixed \\
Number of countries & Yes & Yes \\
$R^{2}$ & 825 & 825 \\
Zero autocorrelation in first-differenced & 112 & 112 \\
Errors test z-statistic ( $p$-value) & 0.839 & \\
\hline
\end{tabular}

Notes: Dependent variable is female share of migrants coming to Germany (in percent). Random country effects included in M1, fixed country effects in M2. Standard errors clustered on countries of origin in parentheses.

${ }^{* * \star}$ Statistically significant at 0.01 level.

** Statistically significant at 0.05 level.

*Statistically significant at 0.1 level.

as classified by the United Nations. ${ }^{10}$ The results presented in Table 2 suggest a positive effect of women's economic rights on the women's share in migrants, which is entirely consistent with the results from our baseline models. Note that this alternative women's rights variable is available for a larger sample of now 122 developing countries.

The next set of tests explores whether our central finding is confounded by omitting variables whose exclusion allows the women's economic rights measure to spuriously pick up a positive and statistically significant effect. Models 5 and 6 , for which the results are reported in Table 3, test whether it is really women's economic rights rather than women's political rights that matter. The Varieties of Democracy Project provides data on women's civil society

10 Specifically, these are the Caribbean, Central America, Central Asia, Eastern Africa, Eastern Asia, Eastern Europe, Middle Africa, Northern Africa, Oceania, South America, South-Eastern Asia, Southern Africa, Southern Asia, Southern Europe, Western Africa, and Western Asia. 
Table 2 Robustness tests: employing an alternative measure of women's rights

\begin{tabular}{|c|c|c|}
\hline & $\begin{array}{c}\text { M3 } \\
\text { World Bank measure }\end{array}$ & $\begin{array}{c}\text { M4 } \\
\text { World Bank measure }\end{array}$ \\
\hline \multirow[t]{2}{*}{ (Women's share of migrants) $_{\mathrm{t}-1}$} & $0.835^{\star \star \star}$ & $0.705^{\star \star \star}$ \\
\hline & $(0.033)$ & $(0.049)$ \\
\hline \multirow[t]{2}{*}{ Women's economic rights } & $0.064^{\star \star \star}$ & $0.057^{\star \star}$ \\
\hline & $(0.021)$ & $(0.023)$ \\
\hline \multirow[t]{2}{*}{ Per capita income } & $0.073^{\star \star \star}$ & 0.040 \\
\hline & $(0.022)$ & $(0.025)$ \\
\hline \multirow[t]{2}{*}{ Growth in per capita income } & 0.034 & 0.023 \\
\hline & $(0.025)$ & $(0.022)$ \\
\hline \multirow[t]{2}{*}{ Democracy (polity2) } & -0.013 & 0.024 \\
\hline & $(0.050)$ & $(0.059)$ \\
\hline \multirow[t]{2}{*}{ Major political violence dummy variable } & -0.324 & -0.731 \\
\hline & $(0.924)$ & $(1.176)$ \\
\hline \multirow[t]{2}{*}{ Distance to Germany (ln) } & $1.549^{\star \star \star}$ & $3.918^{\star \star}$ \\
\hline & $(0.449)$ & $(1.748)$ \\
\hline \multirow[t]{2}{*}{ Visa requirement dummy variable } & $0.861^{*}$ & $3.226^{\star \star \star}$ \\
\hline & $(0.508)$ & $(0.807)$ \\
\hline Country/subregional effects & Random & Subregional fixed \\
\hline Year fixed effects & Yes & Yes \\
\hline Observations & 1,066 & 1,066 \\
\hline Number of countries & 122 & 122 \\
\hline$R^{2}$ & 0.788 & 0.806 \\
\hline
\end{tabular}

Notes: Dependent variable is female share of migrants coming to Germany (in percent). Random country effects included in M3. Subregional fixed effects included in M4. Standard errors clustered on countries of origin in parentheses.

$\star \star \star$ Statistically significant at 0.01 level.

** Statistically significant at 0.05 level.

* Statistically significant at 0.1 level.

participation and political participation. ${ }^{11}$ Civil society participation rights measure the extent to which women are allowed to participate in political debates, participate in civil society organizations, and the estimated share of women among journalists in the country. Political participation is based on the share of women in parliament as well as expert assessments on a 5 -point scale on how strongly the distribution of political power favors men. As can be seen in the results reported in Table 3, independently of which of the two measures of political rights are employed, they have no effect on the gender gap in migration, with the estimates of our women's economic rights measure practically identical to the baseline models.

In the models for which the results are reported in Table 4, we make sure that our baseline model does not miss important nonlinearities in the effect of our central explanatory variable, women's economic rights, and the effect of per capita income, for which nonlinearities in its effect on migration rather than the gender gap in migration has been established. We test for

11 https://www.v-dem.net/en/. 
Table 3 Robustness tests: economic versus political rights

\begin{tabular}{|c|c|c|c|c|}
\hline & $\begin{array}{c}\text { M5 } \\
\text { Civil society } \\
\text { participation }\end{array}$ & $\begin{array}{c}\text { M6 } \\
\text { Civil society } \\
\text { participation }\end{array}$ & $\begin{array}{c}\text { M7 } \\
\text { Political } \\
\text { participation }\end{array}$ & $\begin{array}{c}\text { M8 } \\
\text { Political } \\
\text { participation }\end{array}$ \\
\hline \multirow[t]{2}{*}{ Women's political rights } & 2.668 & 6.747 & 1.834 & -0.025 \\
\hline & $(2.117)$ & $(6.207)$ & $(1.883)$ & $(5.835)$ \\
\hline \multirow[t]{2}{*}{ (Women's share of migrants) $_{\mathrm{t}-1}$} & $0.778^{\star \star \star}$ & $0.426^{\star \star \star}$ & $0.778^{\star \star \star}$ & $0.435^{\star \star \star}$ \\
\hline & $(0.032)$ & $(0.077)$ & $(0.033)$ & $(0.075)$ \\
\hline \multirow[t]{2}{*}{ Women's economic rights } & $0.073^{\star \star \star}$ & $0.083^{\star}$ & $0.076^{\star \star \star}$ & $0.089^{\star \star}$ \\
\hline & $(0.017)$ & $(0.045)$ & $(0.016)$ & $(0.044)$ \\
\hline \multirow[t]{2}{*}{ Per capita income } & 0.064 & -0.482 & 0.073 & -0.410 \\
\hline & $(0.049)$ & $(0.589)$ & $(0.049)$ & $(0.556)$ \\
\hline \multirow[t]{2}{*}{ Growth in per capita income } & 0.055 & 0.021 & 0.050 & 0.022 \\
\hline & $(0.034)$ & $(0.033)$ & $(0.033)$ & $(0.032)$ \\
\hline \multirow[t]{2}{*}{ Democracy (polity2) } & -0.030 & 0.046 & 0.002 & 0.121 \\
\hline & $(0.056)$ & $(0.229)$ & $(0.053)$ & $(0.224)$ \\
\hline \multirow[t]{2}{*}{ Major political violence dummy } & -0.280 & -1.172 & -0.390 & -1.319 \\
\hline & $(1.088)$ & $(3.817)$ & $(1.137)$ & $(3.776)$ \\
\hline \multirow[t]{2}{*}{ Distance to Germany (In) } & $1.677^{\star \star \star}$ & & $1.575^{\star \star \star}$ & \\
\hline & $(0.544)$ & & $(0.566)$ & \\
\hline \multirow[t]{2}{*}{ Visa requirement dummy } & $1.115^{\star}$ & & $1.301^{\star \star}$ & \\
\hline & $(0.610)$ & & $(0.607)$ & \\
\hline Country effects & Random & Fixed & Random & Fixed \\
\hline Year fixed effects & Yes & Yes & Yes & Yes \\
\hline Observations & 824 & 824 & 824 & 824 \\
\hline Number of countries & 111 & 111 & 111 & 111 \\
\hline$R^{2}$ & 0.840 & & 0.839 & \\
\hline Zero autocorrelation in first-diff. & & 1.486 & & 1.429 \\
\hline Errors test $z$-statistic ( $p$-value) & & $(0.137)$ & & $(0.153)$ \\
\hline
\end{tabular}

Notes: Dependent variable is female share of migrants coming to Germany (in percent). Random country effects included in M5 and M7, fixed country effects in M6 and M8. Standard errors clustered on countries of origin in parentheses.

$\star \star \star$ Statistically significant at 0.01 level.

** Statistically significant at 0.05 level.

${ }^{\star}$ Statistically significant at 0.1 level.

this by including the squared term of women's economic rights in Models 9 and 10 and the squared term of per capita income in Models 11 and 12. There is evidence for a nonlinear effect of income in the random effects specification of Model 11 but not its fixed effects counterpart of Model 12. By contrast, there is consistent evidence across both model specifications that the positive effect of women's economic rights is decreasing with higher rights. The implied nonlinearity is quite strong. Based on Model 9, the effect size in countries with low women's economic rights is more than double what the average effect size implied by Model 1 would suggest. It decreases with increasing women's economic rights, becoming statistically indistinguishable from zero from around the 70th percentile. 
Table 4 Robustness tests: allowing for non-linear effects

\begin{tabular}{|c|c|c|c|c|}
\hline & M9 & M10 & M11 & M12 \\
\hline \multirow[t]{2}{*}{ (Women's share of migrants) $_{\mathrm{t}-1}$} & $0.765^{\star \star \star}$ & $0.435^{\star \star \star}$ & $0.778^{\star \star \star}$ & $0.412^{\star \star \star}$ \\
\hline & $(0.034)$ & $(0.074)$ & $(0.034)$ & $(0.071)$ \\
\hline \multirow[t]{2}{*}{ Women's economic rights } & $0.197^{\star \star \star}$ & $0.357^{\star \star \star}$ & $0.070^{\star \star \star}$ & $0.085^{\star \star}$ \\
\hline & $(0.048)$ & $(0.082)$ & $(0.016)$ & $(0.043)$ \\
\hline \multirow[t]{2}{*}{ Women's economic rights sq. } & $-0.001^{\star \star \star}$ & $-0.003^{\star \star \star}$ & & \\
\hline & $(0.000)$ & $(0.001)$ & & \\
\hline \multirow[t]{2}{*}{ Per capita income } & 0.079 & -0.529 & $0.270^{\star \star}$ & 0.326 \\
\hline & $(0.049)$ & $(0.565)$ & $(0.112)$ & $(0.862)$ \\
\hline \multirow[t]{2}{*}{ Per capita income squared } & & & $-0.005^{\star \star}$ & -0.021 \\
\hline & & & $(0.002)$ & $(0.016)$ \\
\hline \multirow[t]{2}{*}{ Growth in per capita income } & 0.051 & 0.021 & 0.055 & 0.012 \\
\hline & $(0.033)$ & $(0.031)$ & $(0.036)$ & $(0.034)$ \\
\hline \multirow[t]{2}{*}{ Democracy (polity2) } & 0.016 & 0.114 & 0.010 & 0.076 \\
\hline & $(0.054)$ & $(0.229)$ & $(0.055)$ & $(0.201)$ \\
\hline \multirow[t]{2}{*}{ Major political violence dummy } & -0.641 & -1.657 & -0.377 & -0.555 \\
\hline & $(1.139)$ & $(3.697)$ & $(1.061)$ & $(3.740)$ \\
\hline \multirow[t]{2}{*}{ Distance to Germany (In) } & $1.635^{\star \star \star}$ & & $1.762^{\star \star \star}$ & \\
\hline & $(0.606)$ & & $(0.596)$ & \\
\hline \multirow[t]{2}{*}{ Visa requirement dummy } & $0.991^{\star}$ & & $1.372^{\star \star}$ & \\
\hline & $(0.591)$ & & $(0.661)$ & \\
\hline Country effects & Random & Fixed & Random & Fixed \\
\hline Year fixed effects & Yes & Yes & Yes & Yes \\
\hline Observations & 825 & 825 & 825 & 825 \\
\hline Number of countries & 112 & 112 & 112 & 112 \\
\hline$R^{2}$ & 0.842 & & 0.839 & \\
\hline Zero autocorrelation in first-diff. & & 1.334 & & 1.387 \\
\hline Errors test $z$-statistic ( $p$-value) & & $(0.1822)$ & & $(0.166)$ \\
\hline
\end{tabular}

Notes: Dependent variable is female share of migrants coming to Germany (in percent). Random country effects included in M9 and M11, fixed country effects in M10 and M12. Standard errors clustered on countries of origin in parentheses.

${ }^{\star \star *}$ Statistically significant at 0.01 level.

** Statistically significant at 0.05 level.

* Statistically significant at 0.1 level.

So far, we have not imposed a restriction on the minimum number of migrants for an observation to enter our estimation sample, so that observations may potentially influence our results that only have a small impact on the aggregate gender gap in migration to Germany. We, therefore, restrict the minimum threshold size of the annual number of migrants coming to Germany from a particular country of origin to 250 and 500, respectively. As the results reported in Table 5 show, restricting the sample to these minimum threshold levels reduces the number of countries of origin in the sample from 112 to 78 and 69, respectively, but does not have a major impact on our central finding. 
Table 5 Robustness tests: restrictions on the minimum size of migrant population

\begin{tabular}{|c|c|c|c|c|}
\hline Minimum number restriction & $\begin{array}{r}\text { M13 } \\
>250\end{array}$ & $\begin{array}{c}M 14 \\
>250\end{array}$ & $\begin{array}{r}\text { M15 } \\
>500\end{array}$ & $\begin{array}{r}\text { M16 } \\
>500\end{array}$ \\
\hline (Women's share of migrants) $_{\mathrm{t}-1}$ & $\begin{array}{l}0.934^{\star \star \star} \\
(0.014)\end{array}$ & $\begin{array}{l}0.753^{\star \star \star} \\
(0.104)\end{array}$ & $\begin{array}{l}0.938^{\star \star \star} \\
(0.015)\end{array}$ & $\begin{array}{l}0.675^{\star \star \star} \\
(0.095)\end{array}$ \\
\hline Women's economic rights & $\begin{array}{l}0.052^{\star \star \star} \\
(0.011)\end{array}$ & $\begin{array}{l}0.077^{\star \star} \\
(0.033)\end{array}$ & $\begin{array}{l}0.053^{\star \star \star} \\
(0.013)\end{array}$ & $\begin{array}{l}0.072^{\star \star} \\
(0.031)\end{array}$ \\
\hline Per capita income & $\begin{array}{c}-0.001 \\
(0.020)\end{array}$ & $\begin{array}{c}0.315 \\
(0.422)\end{array}$ & $\begin{array}{c}-0.026 \\
(0.041)\end{array}$ & $\begin{array}{l}1.046^{\star \star} \\
(0.463)\end{array}$ \\
\hline Growth in per capita income & $\begin{array}{l}0.034^{\star \star} \\
(0.013)\end{array}$ & $\begin{array}{c}0.015 \\
(0.031)\end{array}$ & $\begin{array}{l}0.030^{\star \star} \\
(0.012)\end{array}$ & $\begin{array}{c}-0.010 \\
(0.026)\end{array}$ \\
\hline Democracy (polity2) & $\begin{array}{c}0.003 \\
(0.029)\end{array}$ & $\begin{array}{c}0.262 \\
(0.169)\end{array}$ & $\begin{array}{c}0.005 \\
(0.030)\end{array}$ & $\begin{array}{l}0.381^{\star \star} \\
(0.172)\end{array}$ \\
\hline Major political violence dummy & $\begin{array}{c}0.644 \\
(0.486)\end{array}$ & $\begin{array}{l}-2.308 \\
(2.843)\end{array}$ & $\begin{array}{c}0.498 \\
(0.511)\end{array}$ & $\begin{array}{c}-0.584 \\
(2.276)\end{array}$ \\
\hline Distance to Germany (ln) & $\begin{array}{l}0.642^{\star \star \star} \\
(0.215)\end{array}$ & & $\begin{array}{c}0.461^{\star} \\
(0.254)\end{array}$ & \\
\hline Visa requirement dummy & $\begin{array}{c}-0.066 \\
(0.369)\end{array}$ & & $\begin{array}{c}-0.476 \\
(0.607)\end{array}$ & \\
\hline Country effects & Random & Fixed & Random & Fixed \\
\hline Year fixed effects & Yes & Yes & Yes & Yes \\
\hline Observations & 538 & 538 & 445 & 445 \\
\hline Number of countries & 78 & 78 & 69 & 69 \\
\hline$R^{2}$ & 0.938 & & 0.942 & \\
\hline Zero autocorrelation in first-diff. & & -0.984 & & -2.22 \\
\hline Errors test $z$-statistic ( $p$-value) & & $(0.325)$ & & $(0.026)$ \\
\hline
\end{tabular}

Notes: Dependent variable is female share of migrants coming to Germany (in percent). Random country effects included in M13 and M15, fixed country effects in M14 and M16. Standard errors clustered on countries of origin in parentheses.

*** Statistically significant at 0.01 level.

** Statistically significant at 0.05 level.

* Statistically significant at 0.1 level.

Our final set of robustness tests is applicable only to the fixed effects specification estimated with Blundell and Bond's (1998) one-step system estimator. So far, our results have been based on the default settings in Stata, which presume substantive explanatory variables to be strictly exogenous and allows for the maximum possible length of lags of the lagged dependent variable to be used as instruments - the same applies for maximum lag length of substantive explanatory variables to be used as instruments if these were to be specified as predetermined or endogenous instead of strictly exogenous. ${ }^{12}$ These default settings can be problematic as strict exogeneity may be too strong an assumption and with respect to the maximum lag structure, the concern is typically that using too many lags as instruments results in underestimating

12 In our case, this would be T-2 lags as instruments for the lagged dependent variable and endogenous substantive explanatory variables and $\mathrm{T}-1$ lags for predetermined explanatory variables, where $\mathrm{T}$ is the number of time periods in the sample. 
Table 6 Robustness tests: specifying explanatory variables as predetermined/endogenous and restricting maximum length of lags used as instruments

\begin{tabular}{lcccccc}
\hline Explanatory variables specified as: & $\begin{array}{c}\text { M17 } \\
\text { pred. }\end{array}$ & $\begin{array}{c}\text { M18 } \\
\text { end. }\end{array}$ & $\begin{array}{c}\text { M19 } \\
\text { pred. }\end{array}$ & $\begin{array}{c}\text { M20 } \\
\text { end. }\end{array}$ & $\begin{array}{c}\text { M21 } \\
\text { pred. }\end{array}$ & $\begin{array}{c}\text { M22 } \\
\text { end. }\end{array}$ \\
varimum lag length of explanatory & $\mathbf{T - 1}$ & $\mathbf{T - 2}$ & $\mathbf{2}$ & $\mathbf{2}$ & $\mathbf{2}$ & $\mathbf{2}$ \\
length of dependent variable as instruments & $\mathbf{T - 2}$ & $\mathbf{T - 2}$ & $\mathbf{T - 2}$ & $\mathbf{T - 2}$ & $\mathbf{2}$ & $\mathbf{2}$ \\
\hline (Women's share of migrants) & $0.463^{\star \star \star}$ & $0.477^{\star \star \star}$ & $0.484^{\star \star \star}$ & $0.519^{\star \star \star}$ & $0.508^{\star \star \star}$ & $0.541^{\star \star \star}$ \\
& $(0.058)$ & $(0.058)$ & $(0.068)$ & $(0.067)$ & $(0.067)$ & $(0.065)$ \\
Women's economic rights & $0.106^{\star \star \star}$ & $0.121^{\star \star \star}$ & $0.130^{\star \star \star}$ & $0.159^{\star \star \star}$ & $0.118^{\star \star \star}$ & $0.144^{\star \star \star}$ \\
& $(0.033)$ & $(0.035)$ & $(0.042)$ & $(0.042)$ & $(0.043)$ & $(0.042)$ \\
Per capita income & 0.176 & 0.140 & 0.125 & 0.065 & 0.125 & 0.072 \\
& $(0.108)$ & $(0.090)$ & $(0.093)$ & $(0.081)$ & $(0.093)$ & $(0.081)$ \\
Growth in per capita income & 0.021 & 0.011 & 0.019 & 0.013 & 0.020 & 0.011 \\
& $(0.039)$ & $(0.036)$ & $(0.041)$ & $(0.047)$ & $(0.040)$ & $(0.046)$ \\
Democracy (polity2) & 0.252 & 0.232 & 0.214 & 0.140 & 0.243 & 0.180 \\
& $(0.162)$ & $(0.176)$ & $(0.216)$ & $(0.233)$ & $(0.231)$ & $(0.250)$ \\
Major political violence dummy & -2.435 & 0.352 & -3.386 & 1.050 & -3.506 & 0.752 \\
& $(3.285)$ & $(3.164)$ & $(3.186)$ & $(3.188)$ & $(3.133)$ & $(3.033)$ \\
Country effects & Fixed & Fixed & Fixed & Fixed & Fixed & Fixed \\
Year fixed effects & Yes & Yes & Yes & Yes & Yes & Yes \\
Observations & 825 & 825 & 825 & 825 & 825 & 825 \\
Number of countries & 112 & 112 & 112 & 112 & 112 & 112 \\
Zero autocorrelation in first-diff. & -0.984 & -0.984 & -0.984 & -0.984 & -2.22 & -2.22 \\
Errors test $z$-statistic $(p$-value) & $(0.325)$ & $(0.325)$ & $(0.325)$ & $(0.325)$ & $(0.026)$ & $(0.026)$ \\
\hline
\end{tabular}

Notes: Dependent variable is female share of migrants coming to Germany (in percent). Standard errors clustered on countries of origin in parentheses.

${ }^{* * \star}$ Statistically significant at 0.01 level.

${ }^{\star *}$ Statistically significant at 0.05 level.

${ }^{*}$ Statistically significant at 0.1 level.

the standard errors (Roodman, 2009). In Model M17, we specify the substantive explanatory variables to be predetermined rather than strictly exogenous, in which case the error term in time period $t$ is assumed to be correlated with future realizations of the explanatory variables. In Model M18, we specify the substantive explanatory variables to be endogenous, in which case they are assumed to be contemporaneously correlated with the error term in all time periods. Models M19 and M20 repeat the same but restrict the maximum length of lags used as instruments for the, respectively, predetermined and endogenous explanatory variables to two. Models M21 and M22 are like models M19 and M20, but additionally restrict the maximum length of lags used as instruments for the lagged dependent variable also to two. As can be seen in Table 6, the results are robust to these changes in specification.

\section{Conclusion}

There is tremendous variation across places of origin in the women's share of migrants coming to Germany, variation that is simply too large to be random. We have argued that women's 
economic rights in migrants' countries of origin provide an important explanatory factor. Restrictions on women's economic rights are likely to strip many women of the resources to migrate and curb their agency to make migration decisions. Migration from developing countries to a developed destination country like Germany that is both far away and difficult to reach will often resemble a family (or even wider social kin) investment. Families have to single out one family member for whom they can afford the journey, and in countries in which women's economic rights are restricted, families are likely to opt for a young man rather than a woman. These deterring effects dominate any incentive or push-factor effect that restrictions on women's economic rights may otherwise have for women to migrate to Germany.

Employing high-quality migration data over the time period 2009-2017, we have shown that a higher share of women in the populations of migrants coming to Germany can be expected from developing countries of origin with higher women's economic rights. This finding proved to be robust toward various plausible changes in model specification. Of course, while our macro-analysis of the gender composition of migrant populations corroborates the theoretical prediction, subsequent analyses of microdata collected in the countries of birth of potential migrants can and should be used to test the causal mechanisms we have suggested to exist in this article: restrictions on women's economic rights reduce women's access to and control over resources as well as their agency to make migration decisions.

Do gender imbalances in migrant populations matter? We believe they do. Such gender imbalances not only potentially transfer existing patterns and structures of gender discrimination from the country of origin to Germany, but they also contribute to conflict and tensions among migrant populations and between these populations and the German majority population. For example, since intimate relationships are much more likely within a migrant population than going outside (González-Ferrer, 2006), a significant gender gap may result in frustration among young migrant men and may also delay their integration into German society and negatively affect their economic chances, though it is worth noting that Basu (2017) finds that being married to a native has mixed outcomes on the labor market outcomes of the foreign-born population in the United States. Naturally, there is little Germany can directly do to improve women's economic rights abroad, but its policy toward welcoming refugees who were already on the trek toward Europe rather than taking in refugees from bilateral resettlement programs contributed further to gender imbalances in refugee populations. During the recent crisis, fewer than 10,000 refugees reached Germany through resettlement programs (Wills, 2019), while at least 1.5 million people seeking protection came via the known routes, the vast majority of them are men. More generally, Germany still lacks a comprehensive labor immigration policy for non-EU source countries, which would allow it, amongst other objectives, to promote a better gender balance in immigration.

\section{References}

Baláž, V.; A. M. Williams; E. Fifeková (2016): Migration Decision Making as Complex Choice: Eliciting Decision Weights Under Conditions of Imperfect and Complex Information through Experimental Methods. Population, Space and Place 22(1), 36-53.

Bang, J.T.; A. Mitra (2011): Gender Bias and the Female Brain Drain. Applied Economics Letters 18(9), 829-833. 
BAMF (2019): The Stages of the German Asylum Procedure. Nuremberg: Bundesamt für Migration und Flüchtlinge. https://www.bamf.de/EN/Themen/AsylFluechtlingsschutz/AblaufAsylverfahrens/ablaufasylverfahrens-node.html. last accessed: 4 October 2021

Basu, S. (2017): Household Labor Supply and Intermarriage of Immigrants: Differences by Gender. IZA Journal of Development and Migration 7(1), 1-25.

Barthel, F.; E. Neumayer (2015): Spatial Dependence in Asylum Migration. Journal of Ethnic and Migration Studies 41(7), 1131-1151.

Baudassé, T.; R. Bazillier (2014): Gender Inequality and Emigration: Push Factor or Selection Process? International Economics 139, 19-47.

Beine, M.; S. Bertoli; J. Fernández-Huertas Moraga (2016): A practitioners' guide to gravity models of international migration. The World Economy, 39(4), 496-512.

Beine, M.; S. Salomone (2013): Network Effects in International Migration: Education versus Gender. Scandinavian Journal of Economics 115(2), 354-380.

Blundell, R. W.; S. Bond (1998): Initial Conditions and Moment Restrictions in Dynamic Panel Data Models. Journal of Econometrics 87(1), 115-143.

Boyd, M. (1989): Family and Personal Networks in International Migration: Recent Developments and New Agendas. International Migration Review 23(3), 638-670.

Butsch, C. (2020): Financial Engagement of the Indian Diaspora in Germany: Remitting to India. Population, Space and Place 26(4), e2290.

Curran, S. R.; E. Rivero-Fuentes (2003): Engendering Migrant Networks: The Case of Mexican Migration. Demography 40(2), 289-307.

Czaika, M.; E. Neumayer (2017): Visa Restrictions and Economic Globalisation. Applied Geography 84, 75-82.

Davis, B.; P. Winters (2001): Gender, Networks and Mexico-US Migration. Journal of Development Studies 38(2), 1-26.

De Jong, G.F. (2000): Expectations, Gender, and Norms in Migration Decision-Making. Population Studies 54(3), 307-319.

Docquier, F.; A. Marfouk; S. Salomone; K. Sekkat (2012): Are Skilled Women More Migratory than Skilled Men? World Development 40(2), 251-265.

Donato, K. M.; J. T. Alexander; D. R. Gabaccia; J. Leinonen (2011): Variations in the Gender Composition of Immigrant Populations: How They Matter. International Migration Review 45(3), 495-526.

Faini, R.; A. Venturini (1993): Trade, aid and migrations: some basic policy issues. European economic review, 37(2-3), 435-442.

Ferrant, G.; M. Tuccio (2015): South-South Migration and Discrimination Against Women in Social Institutions: A Two-Way Relationship. World Development 72, 240-254.

González-Ferrer, A. (2006): Who Do Immigrants Marry? Partner Choice Among Single Immigrants in Germany. European Sociological Review 22(2), 171-185.

Gordon, L.W. (2005): Trends in the Gender Ratio of Immigrants to the United States. International Migration Review 39(4), 796-818.

Graham, B.A.; J. R. Tucker (2019): The International Political Economy Data Resource. Review of International Organizations 14(1), 149-161.

Hatton, T. J.; J. G. Williamson (2005): What fundamentals drive world migration?. In Poverty, international migration and asylum (pp. 15-38). Palgrave Macmillan, London.

Heering, L.; R. Van Der Erf; L. Van Wissen (2004): The Role of Family Networks and Migration Culture in the Continuation of Moroccan Emigration: A Gender Perspective. Journal of Ethnic and Migration Studies 30(2), 323-337.

Iqbal, S. (2015): Women, Business, and the Law 2016: Getting to Equal (English). Washington, D.C.: World Bank Group.

Kabeer, N. (1999): Resources, Agency, Achievements: Reflections on the Measurement of Women's Empowerment. Development and Change 30(3), 435-464.

Kofman, E. (2019): Gendered Mobilities and Vulnerabilities: Refugee Journeys to and in Europe. Journal of Ethnic and Migration Studies 45(12), 2185-2199.

Lawson, V. A. (1998): Hierarchical Households and Gendered Migration in Latin America: Feminist Extensions to Migration Research. Progress in Human Geography 22(1), 39-53.

Manchin, M.; S. Orazbayev (2018): Social Networks and the Intention to Migrate. World Development 109, 360-374.

Massey, D. S.; J. Arango; G. Hugo; A. Kouaouci; A. Pellegrino; J. E. Taylor (1993): Theories of International Migration: A Review and Appraisal. Population and Development Review 19(3), 431-466. 
Mayer, T.; S. Zignago (2011): Notes on CEPII's Distances Measures: The GeoDist Database, CEPII Working Paper 2011-25.

Naghsh M. N.; A. Young (2014): Female Brain Drains and Women's Rights Gaps: A Gravity Model Analysis of Bilateral Migration Flows. Discussion Paper No. 8067. Bonn: Institute for the Study of Labor.

Neumayer, E.; T. Plümper (2017): Robustness Tests for Quantitative Research. Cambridge: Cambridge University Press.

Nickell, S. (1981): Biases in Dynamic Models with Fixed Effects. Econometrica 49(6), 1417-1426.

Ortega, F.; G. Peri (2013): The Effect of Income and Immigration Policies on International Migration. Migration Studies 1(1), 47-74.

Roodman, D. (2009): A Note on the Theme of Too Many Instruments. Oxford Bulletin of Economics and Statistics 71(1), 135-158.

Ruyssen, I.; S. Salomone (2018): Female Migration: A Way Out of Discrimination? Journal of Development Economics 130, 224-241.

Tiwari, S.; P. C. Winters (2019): Liquidity constraints and migration: Evidence from Indonesia. International Migration Review, 53(1), 254-282.

United Nations. (2017): International Migration Report - Highlights, (ST/ESA/SER.A/403). New York. https:// www.un.org/en/development/desa/population/migration/publications/migrationreport/docs/MigrationReport2017_Highlights.pdf

Vogler, M.; R. Rotte (2000): The Effects of Development on Migration: Theoretical Issues and New Empirical Evidence. Journal of Population Economics 13(3), 485-508.

Wanner, P. (2016): Why Are so Many Asylum Seekers Male? In a Nutshell \#2, March 2016. Neuchâtel: National Center for Competence in Research.

Wills, T. (2019): EU Breaks Promise of Safe Passage for 50,000 Refugees. Deutsche Welle. https://p.dw.com/ p/3RALw. Accessed 14 October 2019. 
Appendix 1 The gender gap in migrants from developing countries to Germany 2009-2018

\begin{tabular}{|c|c|c|c|c|c|}
\hline & \#Migrants & \%Women & & \#Migrants & \% Women \\
\hline Mali & 5,409 & 7.19 & Sri Lanka & 10,629 & 42.72 \\
\hline Gambia & 18,747 & 8.01 & Congo, Dem. Rep. & 3,459 & 43.60 \\
\hline Guinea-Bissau & 2,568 & 10.51 & Azerbaijan & 20,097 & 43.96 \\
\hline Niger & 1,419 & 12.12 & Rwanda & 1,035 & 44.73 \\
\hline Algeria & 31,840 & 12.50 & Angola & 3,295 & 44.80 \\
\hline Chad & 1,044 & 12.74 & Malaysia & 6,382 & 45.03 \\
\hline Sudan & 7,998 & 14.08 & North Macedonia & 99,909 & 45.27 \\
\hline Guinea & 16,317 & 14.17 & Guatemala & 1,134 & 46.47 \\
\hline Mauritania & 1,101 & 15.44 & Argentina & 8,322 & 46.97 \\
\hline Senegal & 7,204 & 16.21 & Mexico & 32,026 & 47.13 \\
\hline Liberia & 1,096 & 16.51 & Nepal & 8,638 & 48.67 \\
\hline Bangladesh & 16,187 & 17.61 & Uzbekistan & 5,377 & 49.01 \\
\hline Burkina Faso (Upper Volta) & 2,471 & 17.77 & Costa Rica & 2,182 & 49.36 \\
\hline Benin & 2,782 & 19.55 & Vietnam & 47,945 & 49.49 \\
\hline Pakistan & 81,191 & 19.73 & Moldova & 19,666 & 50.34 \\
\hline Sierra Leone & 3,751 & 22.18 & Uganda & 2,226 & 50.36 \\
\hline Côte D'Ivoire & 6,679 & 24.82 & Armenia & 23,275 & 50.46 \\
\hline Eritrea & 66,847 & 26.67 & South Africa & 7,022 & 50.66 \\
\hline Tunisia & 31,364 & 28.68 & China & 177,068 & 50.77 \\
\hline Egypt & 34,608 & 29.44 & Ecuador & 6,135 & 52.09 \\
\hline Afghanistan & 258,268 & 29.61 & Indonesia & 20,770 & 52.97 \\
\hline Libya & 23,799 & 30.00 & El Salvador & 1,278 & 52.97 \\
\hline India & 167,675 & 32.68 & Venezuela & 6,209 & 53.81 \\
\hline Lebanon & 24,276 & 33.01 & Cuba & 6,174 & 54.08 \\
\hline Morocco & 62,907 & 33.26 & Singapore & 4,012 & 54.29 \\
\hline Yemen & 6,304 & 34.57 & Brazil & 62,703 & 54.44 \\
\hline Tajikistan & 6,535 & 34.80 & Honduras & 1,226 & 54.65 \\
\hline Ghana & 25,805 & 35.03 & Turkmenistan & 2,439 & 55.35 \\
\hline Syria & 696,516 & 37.14 & Colombia & 21,714 & 56.33 \\
\hline Iraq & 232,365 & 38.16 & Bolivia & 2,527 & 56.95 \\
\hline Albania & 125,266 & 38.51 & Paraguay & 1,737 & 58.09 \\
\hline Ethiopia & 15,830 & 38.75 & Peru & 7,980 & 60.11 \\
\hline Nigeria & 52,282 & 38.80 & Zimbabwe & 2,287 & 60.25 \\
\hline Iran & 98,936 & 38.80 & Russia & 167,153 & 60.35 \\
\hline Congo & 1,201 & 39.80 & Mongolia & 6,154 & 60.61 \\
\hline Turkey (Ottoman Empire) & 230,513 & 39.87 & Kazakhstan & 16,423 & 60.66 \\
\hline Togo & 5,117 & 40.18 & Ukraine & 86,397 & 60.80 \\
\hline Jordan & 11,184 & 40.29 & Dominican Republic & 5,212 & 62.28 \\
\hline Jamaica & 1,005 & 41.00 & Belarus & 14,306 & 63.88 \\
\hline Georgia & 37,604 & 41.20 & Kyrgyz Republic & 5,508 & 63.98 \\
\hline Serbia & 98,872 & 41.61 & Philippines & 18,539 & 66.61 \\
\hline Myanmar (Burma) & 1,503 & 41.78 & Kenya & 9,281 & 68.24 \\
\hline Cameroon & 20,560 & 42.31 & Thailand & 27,462 & 76.21 \\
\hline Tanzania & 2,081 & 42.62 & Madagascar & 2,407 & 81.14 \\
\hline
\end{tabular}

Note: Only countries shown with total migrant entry of 1,000 or above over the 2009-2018 period. 


\section{Appendix 2 The components of the OECD's Women's Economic Rights Variable}

Discrimination in the family

- Child marriage

- Household responsibilities

- Inheritance

- Divorce

\section{Restricted physical integrity}

- Violence against women

- Female genital mutilation

- Missing women

- Reproductive autonomy

Restricted access to productive and financial resources

- Secure access to land assets

- Secure access to non-land assets

- Secure access to formal financial services

- Workplace rights 
Appendix 3 Description of the World Bank's women's economic rights variable

\section{Going places}

Can a woman apply for a passport in the same way as a man?

Can a woman legally travel outside the country in the same way as a man?

Can a woman legally travel outside her home in the same way as a man?

Can a woman legally choose where to live in the same way as a man?

\section{Starting a job}

Can a woman get a job or pursue a trade or profession in the same way as a man?

Does the law mandate non-discrimination based on gender in employment?

Is there legislation on sexual harassment in employment?

Are there criminal penalties or civil remedies for sexual harassment in employment?

\section{Getting paid}

Does the law mandate equal remuneration for work of equal value?

Can women work the same night hours as men?

Can women work in jobs deemed hazardous, arduous, or morally inappropriate in the same way as men?

Are women able to work in the same industries as men?

\section{Getting married}

Is a married woman not legally required to obey her husband?

Can a woman be head of household or head of the family in the same way as a man?

Is there domestic violence legislation?

Can a woman obtain a judgment of divorce in the same way as a man?

Do women have the same rights to remarry as men?

\section{Having children}

Is there paid leave of at least 14 weeks available to women?

Does the government pay $100 \%$ of maternity leave benefits, or parental leave benefits (where maternity leave is unavailable)?

Is there paid paternity leave?

Is there paid parental leave?

Is dismissal of pregnant workers prohibited?

\section{Running a business}

Can a woman legally sign a contract in the same way as a man?

Can a woman legally register a business in the same way as a man?

Can a woman legally open a bank account in the same way as a man?

Does the law prohibit discrimination by creditors based on sex or gender?

\section{Managing assets}

Do men and married women have equal ownership rights to property?

Do sons and daughters have equal rights to inherit assets from their parents?

Do female and male surviving spouses have equal rights to inherit assets?

Does the law grant spouses equal administrative authority over assets during the marriage? Does the law provide for the valuation of nonmonetary contributions?

\section{Getting a pension}

Are the ages at which men and women can retire with full pension benefits equal?

Are the ages at which men and women can retire with partial pension benefits equal?

Is the mandatory retirement age for men and women equal?

Does the law establish explicit pension care credits for periods of childcare?

Note: Each of these dimensions is coded and the overall women's economic rights index is the percentage share of positive answers to the questions in these dimensions. 
Appendix 4 Descriptive variable statistics

\begin{tabular}{lrrrrc}
\hline Variable & Obs & Mean & SD & Min & Max \\
\hline Share of women among migrant pop. & 825 & 44.70 & 15.74 & 3.91 & 84.55 \\
(Share of women among migrant pop.) & 825 & 45.17 & 15.63 & 3.91 & 84.55 \\
Women's economic rights (OECD) & 825 & 50.68 & 21.40 & 1.07 & 94.83 \\
Per capita income & 825 & 3.97 & 6.59 & -62.08 & 123.14 \\
Growth in per capita income & 825 & 3.12 & 5.53 & -9 & 10 \\
Democracy (polity2) & 825 & 0.12 & 0.33 & 0 & 1 \\
Major political violence dummy variable & 825 & 58.76 & 15.85 & 16.16 & 93.09 \\
Distance to Germany (In) & 825 & 8.63 & 0.56 & 7.06 & 9.69 \\
Visa requirement dummy variable & 825 & 0.84 & 0.37 & 0 & 1 \\
Women's economic rights (World Bank) & 1,066 & 67.02 & 16.59 & 23.13 & 96.88 \\
Women's civil society participation & 824 & 0.71 & 0.16 & 0.06 & 0.95 \\
Women's political participation & 824 & 0.87 & 0.16 & 0.23 & 1 \\
\hline
\end{tabular}

OECD, Organisation of Economic Co-operation and Development.

\section{Appendix 5 List of developing countries in the sample (Models 1 and 2)}

Afghanistan, Albania, Algeria, Angola, Argentina, Armenia, Azerbaijan, Bahrain, Bangladesh, Belarus, Benin, Bhutan, Bolivia, Botswana, Brazil, Burkina Faso, Burundi, Cambodia, Cameroon, Central African Republic, Chad, China, Colombia, Congo (Rep.), Congo (Dem. Rep.), Costa Rica, Côte D’Ivoire, Cuba, Dominican Republic, Ecuador, Egypt, El Salvador, Equatorial Guinea, Eritrea, Ethiopia, Fiji, Gabon, Gambia, Georgia, Ghana, Guatemala, Guinea, Guinea-Bissau, Haiti, Honduras, India, Indonesia, Iran, Iraq, Jamaica, Jordan, Kazakhstan, Kenya, Kuwait, Kyrgyz Republic, Laos, Lebanon, Lesotho, Liberia, Libya, North Macedonia, Madagascar, Malawi, Malaysia, Mali, Mauritania, Mauritius, Mexico, Moldova, Mongolia, Morocco, Mozambique, Myanmar, Namibia, Nepal, Nicaragua, Niger, Nigeria, Pakistan, Panama, Paraguay, Peru, Philippines, Russia, Rwanda, Senegal, Serbia, Sierra Leone, Singapore, South Africa, Sri Lanka, Sudan, Swaziland, Syria, Tajikistan, Tanzania, Thailand, Togo, Trinidad and Tobago, Tunisia, Turkey, Turkmenistan, Uganda, Ukraine, United Arab Emirates, Uruguay, Uzbekistan, Venezuela, Vietnam, Yemen, Zambia, Zimbabwe. 